\title{
パルス式自動平衡形計重機の研究
}

\author{
沢井善三郎・原島文雄・稻葉博 \\ 東京大学生産技術研究所 東京都港区六本木 7-22-1 \\ (昭和 46 年 3 月 24 日 受付)
}

\section{Study on Pulse-Driven Automatic Scale}

\author{
Zenzaburō Sawai, Fumio Harashima and Hiroshi Inaba \\ (Institute of Industrial Science, University of Tokyo, Minato-ku, Tokyo) \\ (Received March 24, 1971)
}

In this paper, automatic beam scale with a pulse motor (stepping motor) is proposed, and the analysis of the system is shown with the experimental results.

Automatic beam scales of self-balancing type are widely used in industry for their high accuracy. However, the measuring time is comparatively long with the scales of this type. Consequently, they are not used as equipment for continuous measurement that requires their fast response.

By the use of a pulse motor as actuator and of an electronic controller, the response time of an automatic beam scale is considerably improved, and digital output signals are easily obtained, because the automatic scale proposed operates as an A-D converter.

The experiments are performed with two scales, one having an accuracy of 1/1000 and the other $1 / 8000$. The experimental results have good correlations with the computation, and it is confirmed that the automatic scales proposed in this paper have excellent performances.

\section{1. まえがき}

工業に和忷る重量計測技術の顕著な動向に自動化の 発展がある.とくに電子技術の進歩とその応用は計量 装置乞れ自体の自動化はもとより, 装置産業に和ける 連続かつ自動的な操業ラインへの導入を可能とした. すなわち, 工業用はかりの自動化は計量機構と計量結 果の表示・記録・卵字・果加重量の計算などを行なう 付属装置, ならびに信号の変換・伝送・調節・制御な どを行なう付加装置に関するものが含まれる，さらに 鉄鋼・石油化学工業などに叔いては, プロセス全体の 運転効率の最適化をはかるため電算機の導入が行なわ れているが，これに適した高精度かつ速応性大なる計 量装置の必要性が增大しつつある.

自動平衡形計重機はてこはかりの送錘を自動化した もので, 工業用としてはもっとも精度が高くホッパ・ スケール，トラック・スケールなどに応用されている。

†第13回自動制御連合講演会で発表 (昭 $45 \cdot 10$ )
しかしながら精度が高い反面，計量に要する時間が比 較的長く連続測定装置としての主要な条件である速応 性に関しては実用的に十分とはいえない。むちろん最 近の装置では送鍾速度を高低速の 2 段階に分けて行な う，いわゆるデュアルモードの送鍾機構を装着したる のが開発され，速応性もかなり改善されてきたが，現 状で注計量精度 $1 / 8000$ 飞和いて 15 秒程度を要し, いまだ改善の余地が残されている. 従来の自動平衡形 計重機は 2 相サーボモータあるいはバランシングモー タなどを駆動源とし，送錘機構にはラック式和もりと ピニオンにより，あるいは和るりをリードスクリこウ によって移送する方法が主として採用されている。 た前記の送鍾速度の高低速切換觉は 2 台のモータを電 磁クラッチなぞで切換える力法が用いられている.

本論文は従来から用いられている計量機構に送錘駆 動源として電気パルスモータ（ステップモータ）を採 用した，いわゆるパルスサーボシステムの自動平衡形 計重機に関するものである. 研究の主目的である速応 


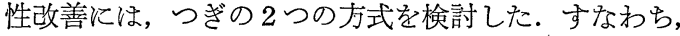
てこの偏位を検出し，これを帰還する従来の方式に加 光て, さらにてこの偏位速度ならびに加速度を検出し， これを帰還する制御方式について計量精度 $1 / 1000$, 感量 $0.1 \mathrm{~g}$ の実験用小形計重機をモデルとし，電算機 による数值解析を含を理論的な検討と実測を行なった。 またいま 1 つの実用的な手段である送鍾速度の多段切 換方式を付加した場合の効果についても実測を行なっ た.この場合，本方式では従来の機械的な手段によら ず，すべて電子回路にようた。

つぎにこれらの基本的な検討の結果，パルスサーボ システムは精度, 速応性ともに従来の方式をらわまわ る性能をもたせることができるとの見通しをえたので さらに工業用自動はかりに実用されている計量機構に よる精度 $1 / 8000$, 科量 $8 \mathrm{~kg}$, 感量 $1 \mathrm{~g}$ の計重機を 試作し実測を行った，この結果，計量時間 10 秒以内 のものを実現することができたので，これについても 併せて報告する。な招自動平衡形計重機にパルスモー 夕を駆動源とした制御方式関する発表は，現在まで のところ国内に物いては筆者ら以外飞ない(1),2，3),4). この方式に近いものとして，てこの偏位をパルス列に 変換し，パルスモータおよびシンクロ発受信機の組み 合わせによって可変周波数に変換し，サーボモータを 制御する方式が開発されているが5)，従来の方式と本 質的な相違はない之考兄られる。また速応性の改善策 として, 電算機を推定器とし, てこの運動から測定荷 重亡つりあう送錘停止位置を予測する方式についての 報告がある゙す。 この方式は，てこの傾きを必ずしも水 平位置にもどす必要がなく，この意味から計量時間を 大幅に短縮できるとされているが，現在のところ実用 化洷っていない，他方，国外飞抒いては Bendix Electronics 社によってリードスクリュウによる送鍵 機構にパルスモータを採用したてんびんが開発され， Physics Exhibition にそのモデルが出品されたと報 告されている?.

\section{2. 原 理 と構 成}

Fig. 1 の単一てこに扔いて支点 0 , 力点 $\mathrm{A}$, 重心 を $\mathrm{G}$ ，てこの質量を $M$ ，力点にかかる総質量を $P$ とす れば，つりあい状態に执いて $\overline{\mathrm{OA}}$ を $l_{1}, \overline{\mathrm{OG}}$ $\angle \mathrm{AOG}$ を $\theta$, 水平線 $\overline{\mathrm{OX}}$ を基線とし $\angle \mathrm{XOA}$ を と拉くと，てこの感度 $S_{e}$ は次式で示される。

$$
\begin{aligned}
S_{e} & =\frac{d \alpha}{d P}=\frac{l_{1} \cos \alpha}{P l_{1} \sin \alpha+M l_{2} \sin (\theta+\alpha)} \\
& =\frac{a}{P h_{1}+M h_{2}}
\end{aligned}
$$

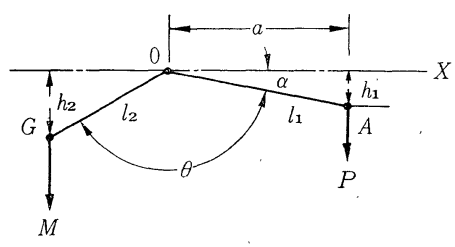

Fig. 1 Principle of a beam scale

つぎに，Fig. 1 の系全体の慣性モーメントをI, 重 力の加速度を $g$ とすれば，てこの運動方程式から固有 振動数 $\omega_{n}$ は次式で示される。

$$
\omega_{n}=\sqrt{a g / I S_{e}}
$$

（2）式より $\omega_{n}$ は慣性モーメントと感度の積の平 方根に反比例する.てこはかりの平衡点付近の応答を 改善するには（2）式の $\omega_{n}$ を高くする必要があるが， $S_{e}$ は計量精度からの拘束条件があり，また $I$ は計量 機構の構造上の制約から，いずれる小さくすることは 容易でないまた，てこ自身の慣性モーメントを小さ くした場合，荷重の大小，送錘位置によって $\omega_{n}$ が可 変パラメータ系となるので，その安定性に問題がある。 前述の送鍾速度の高低速切換方式を採用する理由るこ の点かららなずける。つぎに Fig. 1 のてこ系全体の 伝達関数 $G(s)$ は減衰係数をととすれば次式であた离 られる。

$$
G(s)=\frac{\omega_{n}^{2}}{s^{2}+2 \zeta \omega_{n} s+\omega_{n}{ }^{2}}
$$

また，パルスモータの伝達関数 $G_{0}(s)$ は，かなり複 雑となるが実用的な近似式として 2 次振動系にむだ時 間を加觉ることにより表わされる。すなわち，単一入 力信号に対し，

$$
G_{0}(s)=\frac{1}{s} \cdot \frac{\omega_{0}^{2} \cdot e^{-s i}}{s^{2}+2 \zeta_{0} \omega_{0} s+\omega_{0}^{2}}
$$

ここで, $\omega_{0}$ : パルスモータ固有振動数, $\zeta_{0}$ : パルス モータ減衰係数.

また，パルスモータを送鍾駆動に用いる場合，駆動 パルス周波数がある程度大きい場合，パルス列入力に 対する伝達関数は単に $1 / s$ として近似できる。したが って後述の制御系の解析にあたっては積分器としてい る。また，パルスモータ使用上，とくに注意を要する 点は，慣性負荷の大きさによって始動パルス周波数が 大きく制限されること，特よび正逆転の両方向始動を 要する場合，一方向駆動より始動特性の低下がみられ ること．さらに伝達機構として歯車採用する場合， バックラッシュがあると計量精度への影響のみならず， 騒音を発生し，さらに電気系への雑音源となるので, 機械的精度の向上がとくに要求されることである.

Fig. 2 は試作計重機の機能図を示し, Table 1 そ 


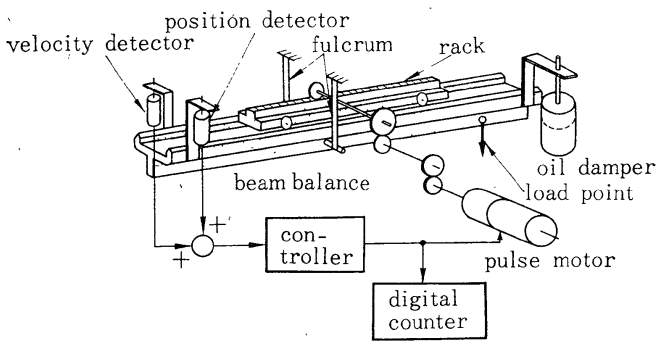

Fig. 2 Schematic diagram for the pulse-driven automatic scale

計量精度 $1 / 1000$ 拈よび $1 / 8000$ の場合の性能を示す。 いずれもラック式送錘を採用し，パルスモータとラッ ク上のピニオンとは 2 組の歯車機構によって連結され ている.てこの偏位の検出は差動変圧器により, また速 度検出には 2 個の円筒形多層巻コイル (各巻数 10000 回, 線径 $0.12 \mathrm{~mm} \phi)$ を差動接続とし，コイル中心に 永久磁石を上下動させるものを用いている１/1000 試作計重機に括ける偏位速度は, 単位重量 $(0.1 \mathrm{~g})$ 更 たり偏位 $50 \mu$, 固有周波数 $1 \mathrm{~Hz}$ とすれば, 直線速 度 $0.2 \mathrm{~mm} / \mathrm{s}$ 之非常に低い. したがって，検出信号は すこぶる小さい. 加速度検出には速度検出器の出力に CR による電気的微分回路を雨入すれば実現可能と考 えられるが，前述のように低レベルで，乙か子雑音の 影響もあって実用的なものをうるに至っていない。

Fig. 3 は単位重量に対する偏位を 1 として基準化 した場合の制御系ブロック線図である。帰還ループは 偏位, 速度, 加速度の 3 つの検出信号による構成を示

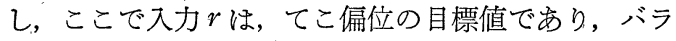
ンスした状態を目標としているので零となる。また，

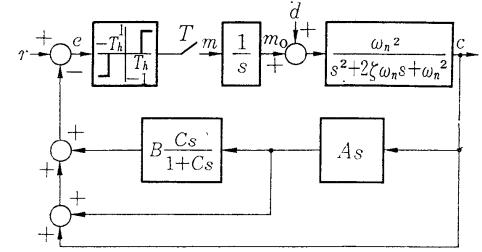

$A$ : velocity feedback gain

$B$ : acceleration feedback gain

$C$ : time constant of accleration detector

$T$ : sampling time

$T_{h^{\prime}}:$ dead band

$\omega_{n}$ : natural frequncy of beam balance

$\zeta$ : damping coefficient of beam balance

$d$ : disturbance (load)

Fig. 3 Block diagram

出力 $c$ は, てこの偏位を表わす量である.

Fig. 4 は制御装置の電気系系統図である. 前述の ように実用的な加速度検出器をうることが困難であっ たので，ここでは，てこの偏位执よび速度検出のみと し, これらを加算, 増幅し必要な検出感度をえている。 A-D 変換部は電圧比較器とトランジスタゲート回路 で構成され, 電圧比較器の基準電圧 $\left( \pm V_{l}, V_{m}, V_{h}\right)$ の極性および大きさを適当汇設定することにより，送 錘移動の方向と速度を自動的飞選別することができる.

ここで, 基準電圧 $V_{l}$ は Fig. 3 亿示す不感带の幅 $T_{h}$ に相当乙, 検出信号が $V_{h}$ 以上では高速パルス駆 動され， $V_{h}$ から $V_{m}$ の間は中速駆動，さらに $V_{m}$ か ら $V_{l}$ までは低速パルス駆動となる。試作装置は基準 電圧可変範囲を大きくとるため検出信号增幅器を低速 用と中，高速用の 2 個を使用しているが，実用的飞，

Table 1 Specification of the scales

\begin{tabular}{|c|c|c|c|}
\hline & $\begin{array}{l}\text { specification } \\
\text { capacity }[\mathrm{g}] \\
\text { sensitivity }[\mathrm{g}] \\
\text { weighing accuracy }\end{array}$ & $\begin{array}{c}1 / 1000 \text { scale } \\
100 \\
0.1 \\
1 / 1000\end{array}$ & $\begin{array}{c}1 / 8000 \text { scale } \\
8000 \\
1 \\
1 / 8000\end{array}$ \\
\hline $\begin{array}{l}\text { beam } \\
\text { balance }\end{array}$ & $\begin{array}{l}\text { moment of inertia }\left[\mathrm{kg} \cdot \mathrm{m}^{2}\right] \\
\text { natural period }[\mathrm{s}] \\
\text { mechanical advantage } \\
\text { rack weigkt }[\mathrm{g}] \\
\text { sliding span }[\mathrm{mm}]\end{array}$ & $\begin{array}{c}\text { about } 0.0196 \\
\text { about } 1 \\
1: 1 \\
100 \\
157\end{array}$ & $\begin{array}{c}\text { about } 1.84 \\
0.92 \\
1: 1.76 \\
4547 \\
440\end{array}$ \\
\hline $\begin{array}{l}\text { pulse } \\
\text { motor }\end{array}$ & $\begin{array}{l}\text { type } \\
\text { angular increment per pulse }[\mathrm{deg}] \\
\text { maxmum pules rate }[\mathrm{pps}] \\
\text { maxmum out put }[\mathrm{HP}] \\
\text { drive unit }\end{array}$ & $\begin{array}{c}\text { Fujitsu AT } 109 \\
2.25 \\
8000 \\
0.05 \\
\text { Fujitsu FANUC } 613 \mathrm{~F}\end{array}$ & $\begin{array}{c}\text { Fujitsu EPM-110 } \\
1.5 \\
8000 \\
0.33 \\
\text { Fujitsu FANUC 617A }\end{array}$ \\
\hline \multicolumn{2}{|c|}{ position detector } & $\begin{array}{c}\text { differential transformer } \\
\quad \pm 2.5 \mathrm{~mm}\end{array}$ & $\begin{array}{c}\text { differential transformer } \\
\pm 2.5 \mathrm{~mm}\end{array}$ \\
\hline \multicolumn{2}{|c|}{ sensitivity of position } & $0.5 \mathrm{~V} / 0.1 \mathrm{~g}$ & $0.4 \mathrm{~V} / 0.1 \mathrm{~g}$ \\
\hline
\end{tabular}




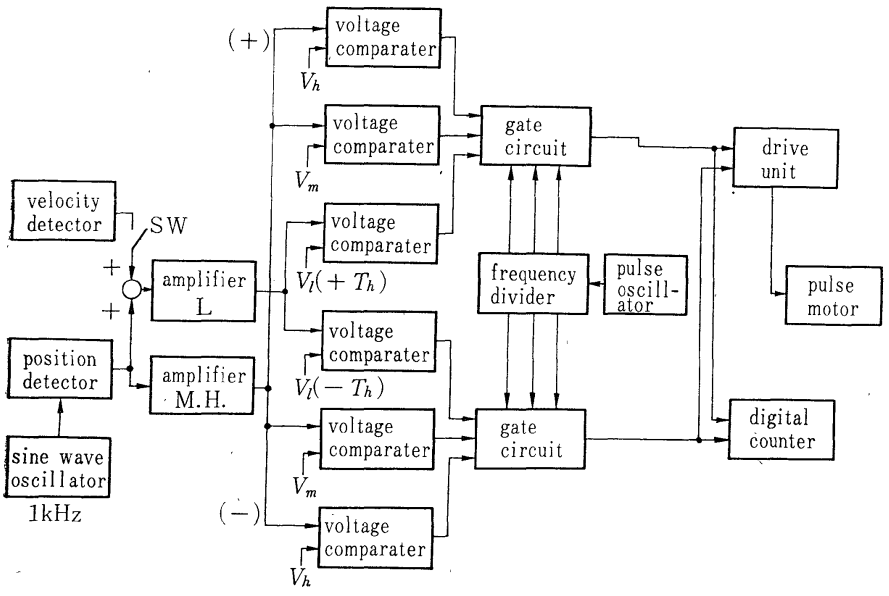

Fig. 4 Block diagram of the controller

1 個とすることは十分可能である。な和歯車比は単位 重量（感量）あたり1パルスとしているので, 駆動パ ルス周波数をディジタルカウンタで測定することによ り直接，測定荷重を知ることができる.

\section{3. 特性の解折および実測結果}

Fig. 3 の制御系の安定性ならびに過渡特性を求め るため，以下に示す数值解析を行なった。 まず，てこ の偏位のみを帰還する場合の閉ループの安定性を知る には，記述関数 (describing function)による方法が ある・すなわち,
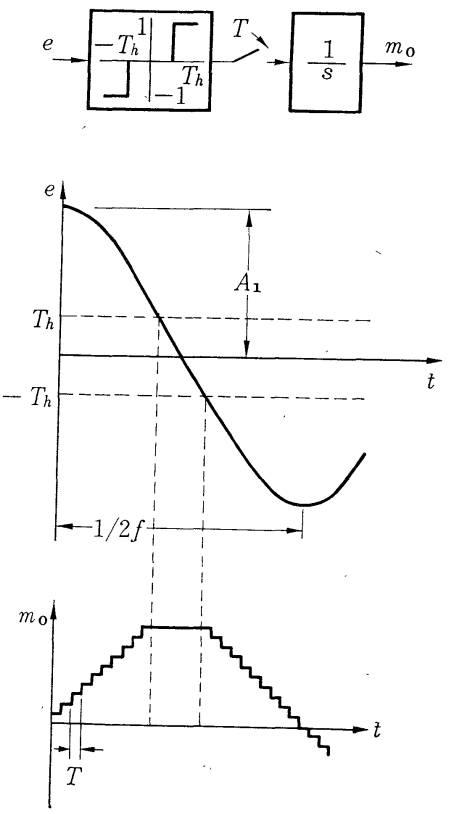

Fig. 5 Input and output waveforms of discribing function
(1) $e(t)=A_{1} \cos \omega t$ とするとサン プリング周波数が $\omega$ より十分大きいこ 之.

（2）不感帯の幅を $T_{h}$ とすれば $A_{1} \gg T_{h}$.

(3) $G(s)$ が低域フィルタと考光 られること。

これらの条件で $e(t)$ と $m_{0}(t)$ の関 係は Fig. 5 に示される. 出力波形 $m_{0}$ ( $t$ ）を三角波で近似し，そのフーリエ 展開したものの基本波成分の振幅を $m_{f}$ とすれば,

$$
\begin{aligned}
& m_{f}=\frac{2}{T \pi^{2} f} \quad \omega=2 \pi f \quad(5) \\
& \text { このとき, } e(t) \text { から } m_{0}(t) \text { までの }
\end{aligned}
$$

記述関数 $N_{D}$ は次式で示される.

$$
N_{D}=\frac{4}{T \pi \omega A_{1}} \varepsilon^{-j(\pi / 2)}
$$

ここで, $T:$ サンプル周期

また， $G(s)$ は $(3)$ 式であたえられ， $-1 / N_{D}=G$ $(j \omega)$ の条件により閉ループ系が不安定となる 発振周 波数 $\omega$ とその振幅 $A_{1}$ は,

$$
A_{1}=\frac{2}{\zeta \omega_{n} T \pi} \quad \omega=\omega_{n}
$$

となる。（7）式は偏位のみ帰還する場合で，ほぼ実 測值と一致することが確かめられた．つぎに応答特性 であるが，本制御方式は非線形サンプル值系で制御動 作が時間的に不連続であるが，数值解析は可能である と考えられる. Fig. 6 は Fig. 3 の制御系を状態変数

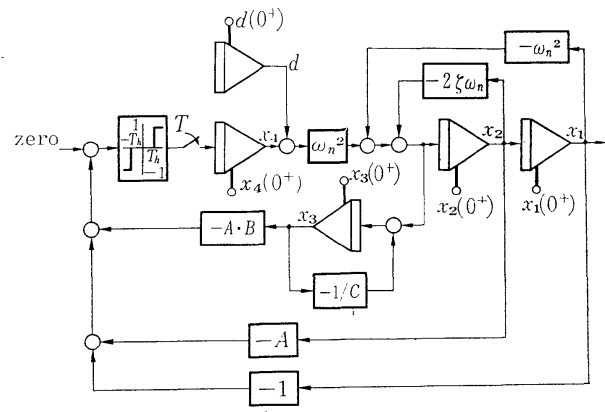

Fig. 6 State-variable diagram of the system 線図で表わしたものである，この系は次のベクトル行 列形式で表わされる.

$$
\begin{gathered}
\frac{d \boldsymbol{v}}{d \lambda}=\boldsymbol{A} \boldsymbol{v}(\lambda), \quad \lambda=t-n T, \quad 0<\lambda \leq T \\
(n=0,1, \cdots \cdots, n) \\
\boldsymbol{v}=\operatorname{col}\left(d, \quad x_{1}, \quad x_{2}, \quad x_{3}, \quad x_{4}\right)
\end{gathered}
$$

(8)式はサンプリング区間内の離散值系を記述する 
状態微分方程式で, この初期条件は次の状態推移方程 式であたえられる。

$$
\boldsymbol{v}\left(n T^{+}\right)=\boldsymbol{B} \boldsymbol{v}(n T)
$$

(8) 式のラプラス変換から,

$$
s \boldsymbol{V}(s)=\boldsymbol{A} \boldsymbol{V}(s)+\boldsymbol{v}\left(O^{+}\right)
$$

したがって，

$$
\boldsymbol{V}(s)=[s \boldsymbol{I}-\boldsymbol{A}]^{-1} \boldsymbol{v}\left(O^{+}\right)
$$

ただし，I：単位マトリクス

$$
\boldsymbol{\Phi}(\lambda)=L^{-1}\left[(s \boldsymbol{I}-\boldsymbol{A})^{-1}\right]
$$

とすれば,

$$
\boldsymbol{v}(t)=\boldsymbol{\Phi}(t-n T) \boldsymbol{v}\left(n T^{+}\right)
$$

Fig. 5 から，（8）式は具体的に，次のように表わ される。

$$
\begin{aligned}
& \dot{d}=0 \\
& \dot{x}_{1}=x_{2} \\
& \dot{x}_{2}=\omega_{n}^{2} d-\omega_{n}^{2} x_{1}-2 \zeta \omega_{n} x_{2}+\omega_{n}^{2} x_{4} \\
& \dot{x}_{3}=\omega_{n}^{2} d-\omega_{n}^{2} x_{1}-2 \zeta \omega_{n} x_{2}-\frac{1}{c} x_{3}+\omega_{n}^{2} x^{4}
\end{aligned}
$$

したがって(付録参照)，

$$
\boldsymbol{A}=\left(\begin{array}{ccccc}
0 & 0 & 0 & 0 & 0 \\
0 & 0 & 1 & 0 & 0 \\
\omega_{n}^{2} & -\omega_{n}^{2} & -2 \zeta \omega_{n} & 0 & \omega_{n}^{2} \\
\omega_{n}{ }^{2} & -\omega_{n}{ }^{2} & -2 \zeta \omega_{n} & -1 / c & \omega_{n}{ }^{2} \\
0 & 0 & 0 & 0 & 0
\end{array}\right)
$$

また，(9) 式のB 行列は, Fig. 6 より次のように なる。

$$
\boldsymbol{B}=\left(\begin{array}{lllll}
1 & 0 & 0 & 0 & 0 \\
0 & 1 & 0 & 0 & 0 \\
0 & 0 & 1 & 0 & 0 \\
0 & 0 & 0 & 1 & 0 \\
0 & 0 & 0 & 0 & 1+Q / x_{4}(n T)
\end{array}\right)
$$

ただし，Qは，

$J=-\left[x_{1}(n T)+A x_{2}(n T)+A \cdot B x_{3}(n T)\right]$ と括けば,

$$
Q=\left\{\begin{array}{cl}
+1 & J \geq T_{h} \\
0 & -T_{h}<J<T_{h} \\
-1 & -J \leq-T_{h}
\end{array}\right.
$$

ゆ光に，任意の初期值 $\boldsymbol{v}\left(O^{+}\right)$があたえられたとき， (11)，(13)，(14)，!(15)，（16）式からステップ応答 夯計算できる。各帰還量 $A, B, C$ を決定する場合, アナログ計算機で概略値を求め, 細部をディジタル計 算機によって求めた.

Fig. 7, Fig. 8 は 1/1000 試作計重機のステテップ 応答の計算結果（パルスモータ軸位置）と実測結果で ある. Fig. 7, Fig. 8 の計算結果で, グラフ初期の階 段状波形はパルスモータ軸位置がステップ状に変化し

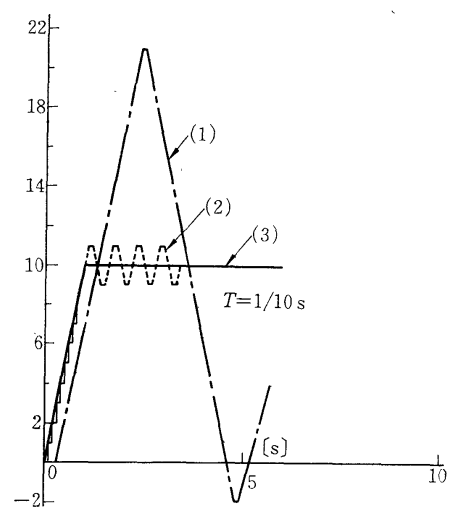
(1) $\omega n / 2 \pi=0.2$,
(2) $\omega_{n} / 2 \pi=1.6$,
(3) $\omega_{n} / 2 \pi=1.8 \sim 2.0, \quad \zeta=0.6, \quad T_{h}=0.6$ (theoretical)

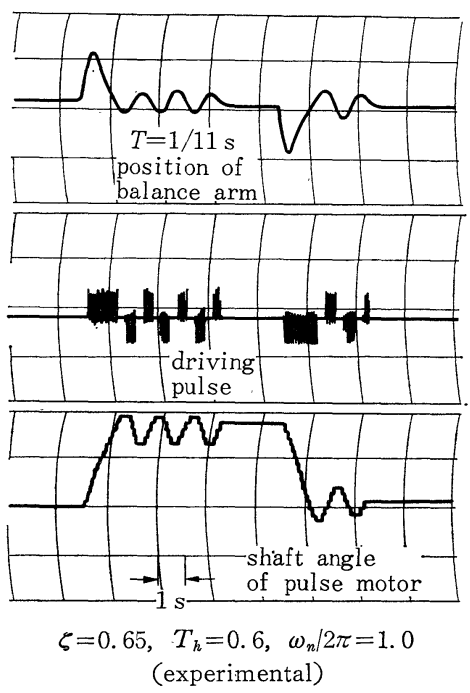

Fig. 7 Computed curves and experimental results (without velocity feedback)

ていることを表わしているものであり，その他の部分 については簡単のため包絡線で表わしている.この場 合, てこの平衡点付近の安定限界は駆動パルス周波数 に执いて $10 \mathrm{pps}$ となる. さらに速度帰還を付加した 場合, 約 $30 \mathrm{pps}$ となり速応性の改善がみとめられた。 また，これらは実測結果とも添添一致する。したがへ てさらに大幅な速応性の改善には加速度帰還が必要と なる。

また，Fig. 9 は計量精度 $1 / 1000$ 計重機の送鍾速度 を3 段階に切換觉た場合のステップ応答の実測值で,

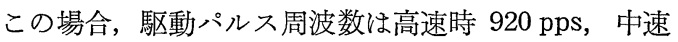
時 $50 \mathrm{pps}$ ，低速時 $7 \mathrm{pps}$ で重点荷重は $50 \mathrm{~g}$ の分銅を 用いた．偏位検出信号の大小により送鋟駆動のパルス 周波数が自動的に切換えられていることがわかる. 塞 


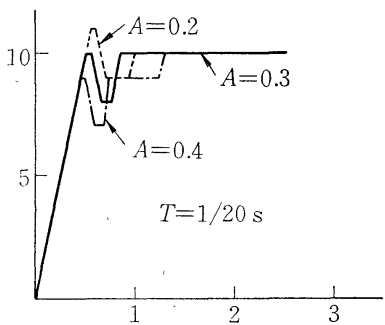

[s]

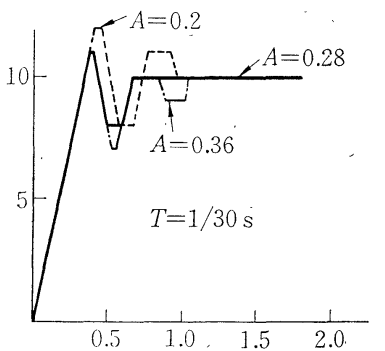

[s]

$\omega_{n} / 2 \pi=1.1, \quad \zeta=0.7, \quad T_{h}=0.8$ (theoretical)

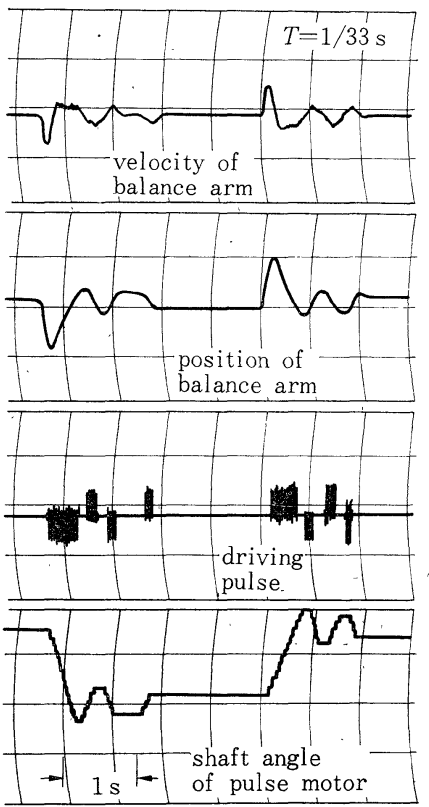

$A=0.25, \quad \zeta=0.65, \quad \omega_{n} / 2 \pi=1.0, \quad T_{h}=0.8$ (experimental)

Fig. 8, Computed curves and experimental results (with velocity feedback)

測結果では偏位が零付近に物いてオーバシュートし符 号が反転しても同一方向のパルスが出つづけている. これは，てこの振動の高周波成分を除去するために， コントローラに挿入したフィルタによる電気的な扰く

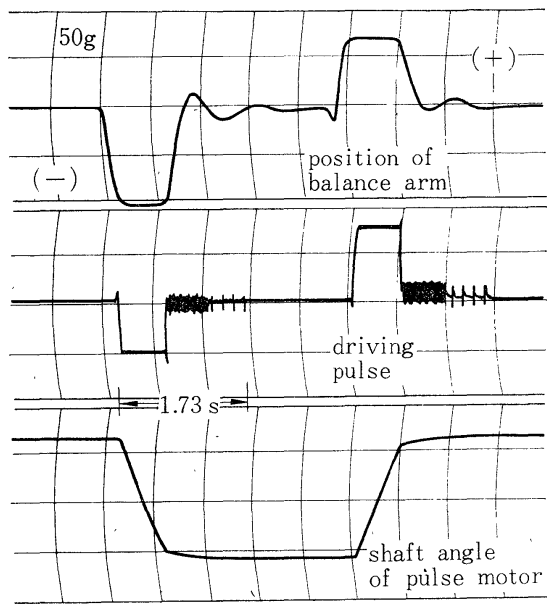

driving pulse

high speed $920 \mathrm{pps}$ middle speed $50 "$ low speed 7 "

Fig. 9 Oscillograms of the transient response $(1 / 1000$ scale $)$

れ(約 $100 \mathrm{~ms}$ ) 飞よるるのでめる。この場合の計量時 間は科量 $100 \mathrm{~g}$ に対し，偏位のみの帰還でも約 $2.5 \mathrm{~s}$ であった。な和高速時のパルス周波数限界を実測した 結果, 約 $1200 \mathrm{pps}$ であった。

試作計重機の数值解折招よび実測結果から, 本制御 方式は従来の方式と比較し, 精度, 速応性とも実用的 に十分対抗でき，また他の方式にみられないすぐれた 特徽を具備するるのが期待できる.

一般に工業用自動平衡形計重機の計量精度は $1 / 3000$ $\sim 1 / 8000$ 程度が多く用いられ，前述の試作計重機汇 この意味に拁いて十分とはい光ない，そこでさらに現 在, 実用されている計量機構にパルスモータを取付け た精度 $1 / 8000$ の計重機を試作し，実測を行なった。

Fig. 10 (a), (b ) は，てこの偏位のみを帰還した場 合の重点荷重に対するステップ応答を記録したもので ある. 送鍾駆動速度の切換光は 3 段階とし, 駆動パル

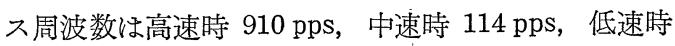
$3.45 \mathrm{pps}$ ，重点荷重は $200 \mathrm{~g} ， 4000 \mathrm{~g}$ の分銅で行なっ た.いずれも低速度のパルス数は $2 \sim 3$ 個で整定し, てこの平衡点付近の安定性も保証され, 必要な精度を 容易に確保することができた。この場合，計量時間は 科量 $8 \mathrm{~kg}$ で約 $10.4 \mathrm{~s}$ であった. また前述の，てこ の偏位速度をさら飞付加しても, 計量時間の短縮

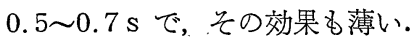

1/8000 試作計重機に招ける駆動パルス周波数限界 を実測したが，約 950〜1000 pps で，これは当初の 推定より $100 \mathrm{pps}$ 程度低い。この原因としては伝達機 


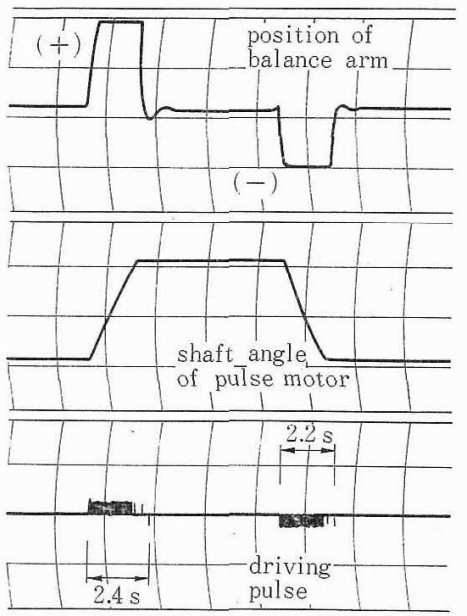

(a) $200 \mathrm{~g}$

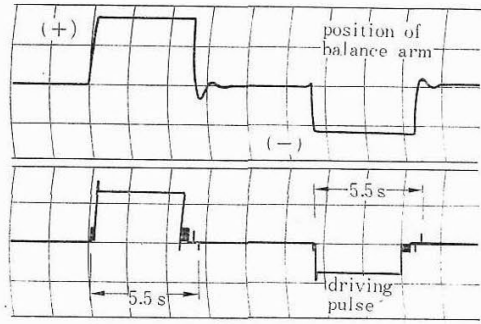

(b) $4000 \mathrm{~g}$

driving pulse

high speed $910 \mathrm{pps}$ middle speed 114 " low speed 3.45 "

Fig. 10 Osillograms of the transient response (1/8000 scale)

搆责含究計量機棈の慣性負荷が，予想上りも大きくな

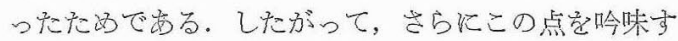

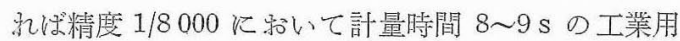
計量装置の実現が期待できる。 Photo. 1 亿計量精度

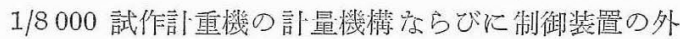
钼苍示す。.

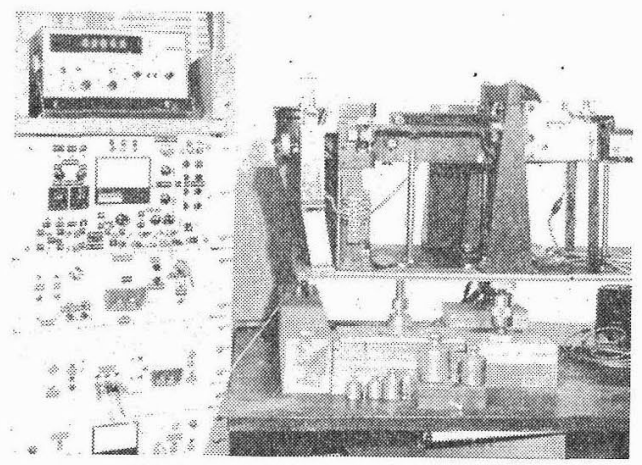

Photo. 1 View of $1 / 8000$ scule

\section{4. 結言}

以上，パルスサーボシステムによる自動平衡形計重 機汇関与る制御方式，制御采の解析，実測結果ならび 飞実用化試験について，关の概略を報告したが，本方 式はつぎのよう矣特徴をるっている。

（1）高精度の確保が容易，か心速応性に関しても 從来の方式よりすぐれている.

（2）計量のディジタル表示が容易, から電算機の 入力装置として直接使用できる。

（3）送錘速度の多段切換光定すべて電子回路によ って行なっている.

（4）機棈部品がずこぶる簡単化されるので，保守 の点からも有利である。

な特，本制御方式を実用化するにあたって，もっと も大きな難点は，パルスモータ駆動装置のコス下高で あるが，これについても必要とする性能に適合した駆 動回路の最適設計, IC 化による電子回路の簡単化, 需要の促進などによりローニスト化の実現が可能で峉 ると考光る. 本研究你 1967 年 4 月, 当時, 本学大学 院学生宮崎文夫君（現在，昭和電工勤務）によって基 碟研究が行なわれ，その後，約 3 年間にわたり行京わ れたものである.この間, 計量機構の試作については

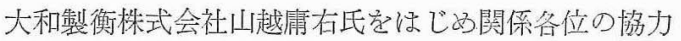
をいただいた。 また，大阪府立大学小野敏郎助教授に は，種々有益な助言を賜った。この機会厚く感謝の 意意する次第でせる。な特，本研究は昭和 43 年， 44 午度支部省科学試騟研究費によったこと党付記す 尚.

$$
\text { 参考文献 }
$$

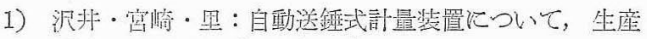
证究, 20-6, 303/304 (1968)

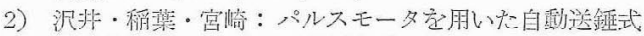

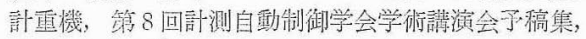
$387 / 388$ (1969)

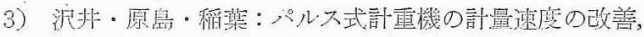
生应研呪, 21-12,35/36 (1969)

4）沢非・原島・稻葉：パルス式自動平衡形計量装置，節

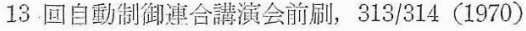

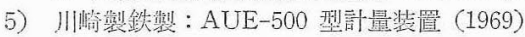

6）椹木・小西・松本：部算機制御家前提とした新しい自 動迄鍎式計量装置の璂成之艺の応月，計装，12-2，47/ 52 (1969)

7) Ideas Applied : Weigh-Boeam Balance With a Controlled Stepping-Motor, Control 11-7, 332 (1967)

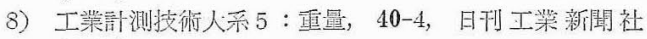
(1965)

9） LA-4 型計量機錼，大和篹衡株式会社，43-3 (1968)

10) J. T. Tou : Modern Control Theory, McGraw-Hill 
(1964)

11) M. Cogniat : La balance automatique «Ugine-Eyraud $\gg$, Mesures-Décembre, No. 307 (1962)

12) J. C. Nicklas: Analysis, Desgin, and Testing of a Position Servo Utilizing a Stepper Motor, Trans. ASME, 85-6 (June-1963)

13）池辺：パルスモータのステップ応答について，計測と 制御, 1-5, 384/394 (1962)

\section{付}

$\Phi(\boldsymbol{t})=\left[\boldsymbol{\phi}_{i j}\right]$ の計算 :

$\Phi(t)=\left(\begin{array}{lllll}\phi_{11} & \phi_{12} & \phi_{13} & \phi_{14} & \phi_{15} \\ \phi_{21} & \phi_{22} & \phi_{23} & \phi_{24} & \phi_{25} \\ \phi_{31} & \phi_{32} & \phi_{33} & \phi_{34} & \phi_{35} \\ \phi_{41} & \dot{\phi}_{42} & \phi_{43} & \phi_{44} & \phi_{45} \\ \phi_{51} & \phi_{52} & \phi_{53} & \phi_{54} & \phi_{55}\end{array}\right)$

$\phi_{11}=1$

$\phi_{12}=\phi_{13}=\phi_{14}=\phi_{15}=0$

$\phi_{21}=\mathcal{L}^{-1}\left[\frac{1}{s} \cdot \frac{\omega_{n}{ }^{2}}{s^{2}+2 \zeta \omega_{n} s+\omega_{n}^{2}}\right]=1-\frac{\varepsilon^{-\zeta \omega_{n} t}}{\sqrt{1-\zeta^{2}}}\left(\sin \omega_{n} \sqrt{1-\zeta^{2}} t \cdot \zeta+\cos \omega_{n} \sqrt{1-\zeta^{2}} \cdot \sqrt{1-\zeta^{2}}\right)$

$\phi_{22}=\mathcal{L}^{-1}\left[\frac{S+2 \zeta \omega_{n}}{s^{2}+2 \zeta \omega_{n} s+\omega_{n}^{2}}\right]=\frac{\varepsilon^{-\zeta \omega_{n} t}}{\sqrt{1-\zeta^{2}}}\left(\sin \omega_{n} \sqrt{1-\zeta^{2}} t \cdot \zeta+\cos \omega_{n} \sqrt{1-\zeta^{2}} t \cdot \sqrt{1-\zeta^{2}}\right)$

$\phi_{23}=\mathcal{L}^{-1}\left[\frac{1}{s^{2}+2 \zeta \omega_{n} s+\omega_{n}^{2}}\right]=\varepsilon^{-\zeta \omega_{n} t} \frac{\sin \omega_{n} \sqrt{1-\zeta^{2}} t}{\omega_{n} \sqrt{1-\zeta^{2}}}$

$\phi^{24}=0$

$\phi_{25}=\phi_{21}$

$\phi_{31}=\mathcal{L}^{-1}\left[\frac{\omega_{n}^{2}}{s^{2}+2 \zeta \omega_{n} s+\omega_{n}^{2}}\right]=\omega_{n}^{2} \times \phi_{23}$

$\phi_{32}=-\phi_{31}$

$\phi^{33}=\mathcal{L}^{-1}\left[\frac{s}{s^{2}+2 \zeta \omega_{n} s+\omega_{n}^{2}}\right]=\varepsilon^{-t \omega_{n} t} \cos \omega_{n} \sqrt{1-\zeta^{2}} t-\zeta \varepsilon^{-\zeta \omega_{n} t} \frac{\sin \omega_{n} \sqrt{1-\zeta^{2}} t}{\sqrt{1-\zeta^{2}}}$

$\phi_{34}=0$

$\phi_{35}=\phi_{31}$

$\phi_{41}=\mathcal{L}^{-1}\left[\frac{\omega_{n}^{2}}{s^{2}+2 \zeta \omega_{n} s+\omega_{n}^{2}} s \cdot \frac{C}{1+C s}\right]=\frac{C \omega_{n}^{2}}{1-2 \zeta \omega_{n} C+C^{2} \omega_{n}^{2}}\left[\left(C \omega_{n}-\zeta\right) \varepsilon-\zeta \omega_{n} t \frac{\sin \omega_{n} \sqrt{1-\zeta^{2} t}}{\sqrt{1-\zeta^{2}}}\right.$

$\left.+\varepsilon^{-\zeta \omega_{n} t} \cos \omega_{n} \sqrt{1-\zeta^{2}} t-\varepsilon^{-(1 / C) t}\right]$

$\phi_{42}=\mathcal{L}^{-1}\left[\frac{-\omega_{n}^{2}}{s^{2}+2 \zeta \omega_{n} s+\omega_{n}^{2}} s \cdot \frac{C}{C s+1}\right]=-\phi_{41}$

$\phi_{43}=\mathcal{L}^{-1}\left[\left(\frac{s}{s^{2}+2 \zeta \omega_{n} s+\omega_{n}^{2}} \cdot-\frac{1}{s}\right) s \cdot \frac{1}{1+C s}\right]=\frac{C}{1-2 \zeta \omega_{n} C+C^{2} \omega_{n}^{2}}\left[\left(C \omega_{n}-\zeta\right) \varepsilon-\zeta \omega_{n} t \cos \omega_{n} \sqrt{1-\zeta^{2}} t\right.$

$\left.-\omega_{n}\left(C \omega_{n} \zeta-2 \zeta^{2}+1\right) \varepsilon^{-\zeta \omega_{n} t} \frac{\sin \omega_{n} \sqrt{1-\zeta^{2}} t}{\sqrt{1-\zeta^{2}}}+\frac{1}{C} \varepsilon^{-(1 / C) t}\right]-\varepsilon^{-(1 / C) t}$

$\phi_{44}=\mathcal{L}^{-1}\left[\frac{C}{1+C s}\right]=\varepsilon^{-(1 / C) t}$

$\phi_{45}=\phi_{41}$

$\phi_{51}=\phi_{52}=\phi_{53}=\phi_{54}=0$

$\phi_{55}=1$ 